Гордана С. ПОКРАЈАЦ* Универзитет у Новом Саду Филозофски факултет
Оригинални научни рад

Примљен: 15. 09. 2018.

Прихваћен: 14. 02. 2019.

\title{
ДОПРИНОС ПАВЛА ПОПОВИЋА ПРОУЧАВАҢУ ДУБРОВАЧКЕ РЕНЕСАНСНЕ ТРАГЕДИЈЕ
}

\begin{abstract}
У ренесансном Дубровнику остварено је богатство у погледу драмског стваралаштва и његове разноврсности - почев од зачетака драме делом Радмио и Љубмир Џора Држића, преко Ветрановићевих светих приказања, потом комедија, трагедија и пасторала других дубровачких аутора. Значај Павла Поповића у истраживању дубровачке ренесансне драме је вишеструк, а посебан књижевноисторијски допринос представља његово проучавање пет дубровачких трагедија из друге половине XVI столећа - Хекубе Марина Држића, Далиде Савка Гучетића Бендевишевића, Јокасте Миха Бунића Бабулиновића, Електре Доминка Златарића и Атаманта Франа Лукаревића Бурине. У раду ће се у првом реду ставити акценат на Поповићев допринос проучавању дубровачког трагичког жанра, у циљу расветљавања његових компаративних веза са хеленским и латинским изворницима.

Кључне речи: ренесанса, трагедија, Дубровник, Хекуба, Далида, Јокаста, Електра, Атаманте, Павле Поповић.
\end{abstract}

Павле Поповић у своме знаменитом делу Преглед српске књижевнос$m u^{1}$ значајну пажњу посвећује књижевности ренесансе у Дубровнику, и у оквиру ње трагичком опусу друге половине XVI столећа. Говорећи о дубровачкој драмској поезији, која се неговала „путем књиге и путем позоришта", Поповић напомиње да нарочите зграде за представе није било; драме су се играле пред Кнежевим двором, потом у великој дворани Великог Вијећа („вијећници”) и најзад, у приватним кућама (пространим палатама). У области трагедије, дубровачки писци су стварали дела која су се одликовала истим особеностима као и у оновременој Италији, будући да су у ренесансном Дубровнику трагички опус и чинила италијанска дела, у извесној мери прерађена. Значајна је Поповићева напомена о највећем трагичком узору, Луцију Анеју Сенеки, из чијих драма „гроза и ужас” прелазе и у италијанску траге-

\footnotetext{
*tadzio.gordana@gmail.com

${ }^{1}$ Павле Поповић, Преглед српске књижевности, Београд, 1909; друго издање - Београд, 1913. године.
} 
дију обележену општим особинама класичних драма (попут хорова, јединства места, јединства времена и сл.). Предмети ових дела потичу из античког света и из оновремених италијанских новела, што се одразило на карактер дубровачких трагедија, међу које Павле Поповић убраја и једно остварење Мавра Ветрановића; оно у основи није трагедија, јер је реч о Орфеу кога Поповић назива „првом трагедијом”, износећи потом са̂м недоумицу - „ако је трагедија". У науци је данас јасан став да је Орфео митолошка еклога, а прва дубровачка ренесансна трагедија је, од укупно пет из друге половине XVI столећа, трагедија Хекуба Марина Држића.

Приликом отварања комплексног проблема везаног за трагедију Хекуба која је до XX столећа остала у рукопису르, неопходно је указати на коначно усаглашен став у историји књижевности поводом њеног ауторства, јер је дуго времена владало мишљење да је творац трагедије Мавро Ветрановић $^{3}$. Овим поводом је Петар Колендић на самом почетку XX столећа заузео јасан став: „Након готово четири вијека можемо мирне душе рећи: Марин Држић је написао Хекубу, која се је дојако сматрала Ветранићевијем дјелом" (Колендић 1905: 140). Павле Поповић је својим истраживањима допринео да се по питању ауторства Хекубе Ветрановићево сведочење у прилог Држићу обелодани, те коначно изнесе јасан став у науци да је она Држићева, а не Ветрановићева; дакле, поменута трагедија је до недавно приписивана Ветрановићу, ,али се пре кратког времена нашло да је Држићева” (Поповић 1909a: 223). Поповић износи недвосмислен закључак да Држић ову трагедију није превео са грчког оригинала, него са истоимене италијанске прераде Лодовика Долчеа; он истиче: „То је Еурипидова Хекуба, али прерађена од Лодовика Долчеа, италијанског драматичара. Држић је веран изворнику, има мања испуштања у тексту и измене" (Поповић 1909б: 224). Овакав став је непосредно након њега истакао и Бранко Водник (Водник 1913), а следили су га потом и други проучаваоци у ХХ веку, почев од П. Колендића, а затим и М. Комбола, Ф. Швелеца, Д. Павловића, М. Франичевића и Ф. Чалеа. Потврду исправности Поповићевог става видимо и у чињеници да је управо почетком XX столећа, Петру Колендићу снажан аргумент пружио један до тада непознат шеснаестовековни шибенички рукопис, на коме је дословно писало: „Изета из Еврипида Екуба, трагедија Марина Држића Дубровчанина, приказана у Дубровнику од славне и вриједне Дружине од бизара годишта 1559. на 29. месеца ђенара" (Колендић 1964: 128). Мишљење Павла Поповића везано за измене дубровачког драматичара у односу на изворник,

\footnotetext{
${ }^{2}$ M. Brlek, Rukopisi samostana Male braće u Dubrovniku, I, Zagreb, JAZU, 1952. - S. Kastropil, Rukopisi Naučne Biblioteke u Dubrovniku, I, Zagreb, JAZU, 1954. - Милан Решетар истиче да је Хекуба сачувана у рукопису Фрањевачке библиотеке у Дубровнику (под бр. 39) који се састоји из два дела, од којих је први написан „неправилном руком из краја XVII вијека или почетка XVIII” (Решетар 1930а: 32). Хекуба је насловљена засебним латиничним натписом: Хекуба, трађедија Еурипида грчкога спјеваоца, у словински језик принесена по Д. Мару Ветрани Чавчићу Дубровчанину, калуђеру и опату мелитенскому. Примину на 15. Ђенара 1576. Решетар наводи да је Ђ. Даничић овај рукопис употребио за своје издање Хекубе, под ознаком „dubr.” (Решетар 1930б).

${ }^{3}$ Хекубу су као дело М. Ветрановића 1853. године приредили Вјекослав Бабукић и Антун Мажуранић.
} 
подразумева Држићеву надградњу и свесну тежњу да пружи сопствени стваралачки печат овој драми. Иако Поповићева тврдња искључује чињеницу да је Држићева трагедија заиста аутентична, значајно је ипак нагласити да је она у дубровачком препеву изразито држићевска. Павле Поповић је узео учешће и у расветљавању могућег места на коме се ова трагедија изводила пред публиком; он изриче тачан став, по коме нарочите зграде за представе XVI века није било, те да су се драме „светског садржаја” играле пред Кнежевим двором (Поповић 1909в: 219), у лепој, поплочаној и доста широкој улици, међу најлепшим зградама Дубровника.

Истражујући трагедију Далида $a^{4}$ Савка Гучетића Бендевишевића, Павле Поповић износи сопствени став по коме је Гучетић „најзначајнији” од свих писаца трагедија; због тога Далиди и посвећује највише пажње, не само у Прегледу српске књижевности, него и у исцрпној студији под насловом Савко Гучетић, дубровачки песник XVI века ${ }^{5}$. Тачан је Поповићев став да је ово по обиму највећа дубровачка трагедија, која обилује „најгрознијим и најужаснијим" сценама ${ }^{6}$, а он у поменутој студији (Поповић 2000а: 345-359) пружа исцрпну анализу предмета, радње, драмских јединстава места и времена, као и карактера и дикције, у циљу пружања оцене Гучетићевог дела. На основу оновремених важећих критеријума у проучавању драмских остварења, П. Поповић је дошао до драгоцених закључака, истакавши да је дубровачки драматичар у погледу стила, а подражавајући италијанске узоре, применио поступке који ће тек наступити у барокном периоду; уједно је био и претеча дубровачком маниризму, а само је његова трагедија (за разлику од осталих које су представљале препеве и прераде), према Поповићевом мишљењу, показала аутентичност у контаминацији два изворника, у интерполацији нових сцена, као и у појединостима својственим особеном дубровачком ареалу. Предмет трагедије, истиче Поповић, није из античког света, него из италијанске новелистике. У питању је шеснаестовековна новела Луиђија да Порте 7 из кога је потекао не само Гучетићев италијански изворник $А д р и а н a^{8}$ Лодовика Грота, него и Шекспирова трагедија Ромео и Ђулијета.

${ }^{4}$ Dalida trađedija Ludovika Grota, koji se zvaše Slijepac od Adrije, prineseno iz italijanskoga jezika u pjesni slovinske po gosp. Savinu de Gozze vlast. Dubrovačk. koje se zvaše Savko Bendevišević i priminu godišta Gospodinova 1603, u: Djela Savka Gučetića Bendeviševića, SPH, knj. XVI, Zagreb, 1888.

${ }^{5}$ Pavle Popović, Savko Gučetić, dubrovački pesnik XVI века, Глас CKA, 1930, CXXXVIII, 3-58, у књ.: Павле Поповић - Дубровачке студије, књ. IV, прир. З. Бојовић, Завод за уџбенике и наставна средства, Београд, 2000, 308-359.

${ }^{6}$ Далида је у односу на остале дубровачке трагедије особена не само по избору теме (потресне судбине кћери адријског краља Атрија), него и по чињеници да је најдраматичнија и у највећој мери обилује сценама ужаса и крви, дакле оном сенековском суровошћу нарочито омиљеном међу ренесансном публиком.

7 Луиђи да Порта 1524. године пише Новелу (La Novella), коју половином XVI столећа преузима Матео Бандело уврстивши је у своју збирку новела и насловивши је Кобна смрт двоје несрећних љубавника (La sfortunata morte di due infelicissimi amanti). Најзад, Банделову новелу преузима Ђерардо Болдијери - потписавши се псеудонимом Вероњанин Клициа (Clizia Veroneze) и ствара еп Љубав Булије и Ромеа (Dello amore di Giulia e di Romeo).

${ }^{8}$ Lodovico Groto, Hadriana, tragedia nova di L. Groto, Milano, 1619. - Поповић доноси податак о години 1578. када је Грото написао своју трагедију (Поповић 2000б: 319). 
Поповић напомиње да Гучетић „није ишао за новелистима - Шекспира, наравно, није ни знао -; он се држао само Грота" (Поповић 2000в: 324). Место радње је и код Грота Адрија, време се односи на староримску повест и сукоб Латина и Сабињана, али је Гучетић, истиче П. Поповић, себи допустио извесне промене: оне су „каткад мале”, више спољашње. За све што каже, Поповић наводи и примере; као што је Грото извршио измене у именима својих актера у односу на она која се налазе у новелама, тако је и Гучетић променио извесна имена која се налазе код Грота. Хадриана је у дубровачкој обради - Далида, Латино - Оронте, Мезенцио - Измар, краљица је изгубила име Оронтеје и остала безимена, док је њен безимени син - који гине у двобоју са Оронтом - добио име Фламиније. Поред ових мањих измена, Поповић указује и на оне веће које је извео дубровачки писац - знатно је смањио улогу хора, а полухор избацио: „У Гучетића, IV, 3, има редовник којега у Грота нема. Могло би се сматрати да је то у неку руку траг „редовника̂” (sacerdoti) који сачињавају полухор, којега Гучетић нема" (Поповић 2000г: 325). Он даје примере Гучетићевих знатнијих измена у тексту, будући да је самостално додавао одређене сцене, мењао њихов распоред у чиновима, као и саме чинове поступком сажимања два Гротова чина у један свој.

Везано за проблем извора Далиде, све до времена Павла Поповића у науци је владало уврежено мишљење да је трагедија настала састављањем две Гротове трагедије, Далиде и Хадриане. Детаљним поређењем Гучетићевог дела и ових извора, Поповић долази до једног у потпуности новог открића које је револуционарно за проучавање генезе Гучетићеве трагедије; установио је да је дубровачки писац од ова два дела користио само Хадриану, а да се она поклапа са сва четири, осим са последњим чином Далиде. Одстарнио је недоумице претходних проучавалаца (Долчи ${ }^{9}$, Апендини ${ }^{10}$, Љубић ${ }^{11}$, Шафарик $^{12}$, Павић ${ }^{13}$, Јиречек ${ }^{14}$ и други, који понављају исте ставове, „очевидно сви један по другом" (Поповић 2000д: 317$)$ ) и доказао да се Гучетић у петом чину као извором послужио трагедијом Орбека Ђамбатиста Ђиралди Чинтиа из 1541. године ${ }^{15}$ (Orbecche Tragedia di M. Gio. Giraldi Cintio ${ }^{16}$ ) и да је управо она ушла, као последњи чин, у дубровачку трагедију Далида. Павле Поповић истиче да је један примерак Орбеке (под насловом Orbecche Tragedia) стигао у Дубровник већ 1549. године, а његовим открићем о овој трагедији као извору петог чина Далиде, омогућено је да се разумеју све измене које

\footnotetext{
${ }^{9}$ Sebastianus Dolci, Fasti Litterario Ragusini, Venetiis, 1767.

${ }^{10}$ F. M. Appendini, Notizie istorico-critiche sulle antichità, storia e letteratura de' Ragusei, Ragusa, II, 1803.

${ }^{11}$ Simeone Gliubich, Dizionario biografico degli uomini illustri della Dalmazia, Vienna, 1856.

${ }^{12}$ P. J. Šafárik, Geschichte der südslawischen Literatur II. Illirisches und kroatisches Schriftthum, Prag, 1865.

${ }^{13}$ A. Pavić, Historija dubrovačke drame, Zagreb, 1871. 1899.

${ }^{14} \mathrm{~K}$. Jireček, Beitrage zur ragusanischen Literaturgeschichte, Archiv für slavische Philologie,

${ }^{15}$ Ово је година у којој је, према речима Фердинанда Нерија, трагедија Орбека играна у ауторовој кући, пред публиком и у присуству ферарског војводе Еркола II Естеа (Нери 1904: 59).

${ }^{16}$ Le tragedie di M. Gio. Battista Giraldi Cintio, Venezia, 1583.
} 
је Гучетић извео у односу на италијански предложак, уобличивши разложно ток драмске радње у целости.

Поповић закључује да је „добро што нам је Гучетић дао у својој трагедији Ђиралдијеву Орбеку. Ма колико да је она гнусна по својим ужасима" (Поповић 2000ћ: 346), ипак представља један од највећих књижевних догађаја свога века. Њен превод који је извео Савко Гучетић, несумњиво ,је добитак за нашу књижевност", сматра Поповић, констатујући како дубровачка књижевност постепено „добија све више система”. Значај Гучетићевог превода Ђиралдијеве Орбеке је драгоцен, будући да смо тиме добили једног истакнутог представника италијанске књижевности „којега нисмо знали да имамо у нас, и видели смо да дубровачка трагедија показује исти интелигентни развој, као и остали родови, и исту пажљиву систематичност" (Поповић 2000e: 346).

Књижевни изворник трагедије Јокаста Миха Бунића Бабулиновића, коју је 1880. године приредио С. Жепић према рукопису из збирке бискупа Штросмајера ${ }^{17}$, био је такође предмет проучавања Павла Поповића. Један од првих историчара књижевности који се поближе бавио Јокастом јесте Армин Павић (Павић 1871a: 41) и хронолошки је смешта након Држићеве Xeкубе. Поповић такође следи овакав став, наводећи да је Бунић „други радник на трагедији", међутим, у науци је усаглашено мишљење да је Гучетићева Далида друга, а Јокаста трећа трагедија. Павле Поповић се надовезује и на Павићев став по коме је Јокаста превод Еурипидових Фениса (Феничанки), али не са грчког оригинала, него са италијанске прераде Лодовика Долчеа. Поповић, према томе, јасно истиче да је Бунићева Јокаста дело Еурипидово, односно у питању су Еурипидове Феничанке, које је приредио Лодовико Долче. У своме осврту на тебанску митску тематику Павле Поповић сажето каже - ова трагедија представља познату свађу браће у „Тиви” (Теби), Етеокла и Полиника, синова Едипових и Јокастиних. Потоњи је с војском напао „Тиву” којом бесправно столује рђави Етеокло. Обојица погину делећи мегдан, а њихова мати Јокаста се због тога убије; Едип бива прогнан и одлази са кћери Антигоном. Ова трагедија је, према Поповићевим речима, проста и јасна и нема много сцена ужаса. Његов став се односи на сцене у којима се трагички патос не очитује у призорима пуним крви и ужаса, мада Бунић открива реално песимистичку слику људске егзистенције, човекову ништавност и кратковекост којом управља ,зла чес".

Иако Бунићева трагедија није играна на сцени, на неколико места долазе до изражаја одмерени призори окрутности на које алудира П. Поповић, обавијени тамном еурипидовском атмосфером. На пример, сугестивно је предочена Јокастина обзнана да је Едипу родила два сина и две кћери, а он је потом - откривши тај „худи пир” - подигао руку на себе ,јак биесна ка год звир;/ сам себи немио избоде позоре,/ да му вик дан био осванут не море” (Бунић Бабулинов 1880a: 8). Поповићев исказ о одмереном присуству сцена ужаса,

17 Jocasta, Tragedia istomačena po Mihu Bona Babulinowu Vlastelinu Dubrav., y: M. Bunić Babulinov, Djela, SPH, knj. XI, Zagreb, 1880. 
имплицитно обухвата и друге ситуације у Бунићевом делу. Речју гласника дочарана је смрт Креонтовог сина Менечеа (Менекеја) који је, пробовши се мачем, изазвао „грозне сузе” свих присутних. Немоћна да спречи покољ међу синовима, Јокаста слуша сведочење гласника о крвавом покољу и мноштву рањених и убијених. Као што је обичај у италијанским и дубровачким ренесансним трагедијама, гласник и овде беседи о окрутним догађајима страдања и патњи актера, по узору на хорацијевску „сведокову речитост” - Полиник је први ранио Етеокла посекавши му ногу, а онда му мачем распори утробу. Најзад, пластично је представљена и сцена краљичиног самоубиства. Јокасту је, видевши синове који леже у крви, опхрвала неизмерна бол, па извуче Етеоклу нож из срца и „сама промаче тој себи њим грло,/ и међу оба два крвава с сузами/ туј паде, и мртва грлећи их руками" (Бунић Бабулинов 1880б: 79). Павле Поповић узима у обзир ауторову намеру да у античку тематику унесе дух ренесансног времена, а посредно и дубровачког окружења, покрећући при томе суштинске проблеме - смрти, судбине, жудње за златом, пролазности и феномен људске нарави.

Следећа у низу од пет трагедија друге половине XVI столећа је Елек$m p a^{18}$ Доминка Златарића. У избору ове трагедије Златарић је, сматра П. Поповић, показао добар књижевни укус, као што је то уосталом показао и преводом Пирама и Тизбе из Овидијевих Метаморфоза. Павле Поповић у Прегледу српске књижевности конкретно каже да је Златарић љубавном новелом из класичног света - Љубав Пирама и Тизбе - коју је он „само превео”, дао једну од „најлепших ствари” у дубровачкој књижевности XVI века. Сам избор оваквих дела античке књижевности, како грчке тако и латинске, сведочи о васпитаном укусу дубровачког писца, као и његовој ерудитској образованости. Поповић напомиње једну значајну чињеницу ${ }^{19}$ - Доминко Златарић није као остали дубровачки писци трагедија учинио превод или прераду италијанског дела, него је превео Софоклову Електру, класичну грчку трагедију и прво веће дело из грчке књижевности у дубровачком преводу. Он закључује - „Трагедија ова лепо је преведена, и то с оригинала” (Поповић 1909г: 227). Павле Поповић је у складу са јасним гледиштем који званично влада у историји дубровачке књижевности - М. Комбол (Комбол 1933: 212-251), Ж. Дер (Дер 1938: 73-88), И. Сламинг (Сламинг 1968: 707-727), М. Франичевић (Франичевић 1968: 71-97), 3. Бојовић (Бојовић 1992: 119-128) - заступао мишљење да је Доминко Златарић први у старом Дубровнику преводио са грчког оригинала, оставши доследан Софокловој оригиналној замисли митске повести о Електри.

Поповић у своме разматрању даје осврт на митолошку грађу везану за повратак из Троје, када Агамемнона убију жена Клитемнестра и њен љубавник Егист; Електра - сматрана робињом након смрти оца Агамемнона - једва чека повратак Ореста (склоњеног негде далеко) који ће доћи и казнити

${ }^{18}$ D. Zlatarić, Elektra, y: Djela Dominka Zlatarića, SPH, knj. XXI, Zagreb, 1899.

${ }^{19}$ Изнео ју је и његов претходник у проучавању ове дубровачке трагедије, Армин Павић, који истиче како је Златарић настојао да грчки оригинал што тачније преведе, те је ,преводилац у точности и красоти све получио што је овако сапет получити могао" (Павић 1871б: 55). 
кривца. Поповић истиче да „ово суморно и ужасно дело Софоклово, које је Златарић штампао 1597. године, износи освету Електре и Ореста над њиховом матером" (Поповић 1909д: 227). Освета Електре и Ореста коју посебно истиче у своме излагању Павле Поповић, односи се на намеру аутора трагедије да се усклади са изабраном темом - злокобном и мрачном, обликујући је кроз слике упечатљиве окрутности својствене освети. Италијански ренесансни теоретичар трагедије Ђанђорђо Трисино у својој Поетищи из 1529. године (објављеној у XVIII столећу ${ }^{20}$ ), напомиње да се окрутни поступци славних људи не смеју расплинути у смислу да се, на пример, не сме изменити чињеница како је Клитемнестру убио њен син Орест; вреди узети у обзир да до оваквог чина долази свесно. Софоклов Орест од детињства потхрањује своју осветничку намеру, а њему је наклоњено Делфијско пророчиште, јер je у питању праведна побуда за осветом; дакле, праведна намера кажњавања која се поклапа са Аполоновим пророчанством, показује да он - иако није експлицитно наредио Оресту матероубиство - наглашава како Орестов чин има његово потпуно одобрење. Излажући о праведној освети у овој трагедији, Поповић алудира на Златарићевог Ореста који, у складу са хеленским изворником убија Клитемнестру, а Електра махнито виче нека удари и другом руком; тим гестом, она уз брата такође постаје виновником освете. Говорећи о овој трагедији, Павле Поповић константно има на уму основни текст према коме, на Клитемнестрино преклињање за милост, Електра подсећа мајку да се ни она у својој окрутности није хтела смиловати њиховом оцу. Краљица уз ужасне вапаје дозива Егиста, а хор све прати коментаром да читав град врви од силног гнева. У подтексту Поповићевог осврта на освету деце над мајком, находи се усклађеност са свевременим праведним ставом својственим трагичком промишљању - окрутну мајку је сустигла заслужена казна и ,згађа се сад оној што се је желило" (Златарић 1899: 63).

Хронолошки последња дубровачка ренесансна трагедија - Аmаманте 21 Франа Лукаревића Бурине - код Павла Поповића претходи Гучетићевој Далиди и Златарићевој Електри, па је у његовом излагању о трагичким делима трећа по реду (следи након Бунићеве Јокасте). Поповић каже да Атаманте представља превод и прераду истоименог дела Јеронима Цопија (Ђиролама Зопиа) из 1579. године 22 . Превод је изведен „по познатом, врло слободном начину свих дубровачких преводилаца" (Поповић 1909ђ: 224); шири је од оригинала и у њему су неки стихови испуштени а неки нови додавани. Павле Поповић истиче да је драма подељена на чинове и сцене, а потом даје сажет увид у тематику дела, као што чини и поводом четири преостале трагедије. Краљ Атамас (Атаманте) приноси на жртву „расрђеним боговима” кћер Хеле и сина Фрикса не би ли спасао „Тиву” (Тебу) од суше и глади. Деца „чудним

\footnotetext{
${ }^{20}$ Giovan Giorgio Trissino, La Poetica, y: Tutte le opera di Giovan Giorgio Trissino, Verona, presso Jac. Villarsi, 1729.

${ }^{21}$ Athamante, tragedija iztomačena po Franu Luccari Burinni, vlastelinu dubrovačkomu, u: Djela Frana Lukarevića Burine, SPH, X, Zagreb, 1878.

${ }^{22}$ Girolamo Zoppio, Athamante tragedia degli Academici Catenati, In Macerata, Appresso Sebastiano Martellini, 1579.
} 
случајем" бивају спасена и одведена на златоруном овну преко мора, где се Хеле удави. Поповић у најкраћим цртама каже како Атамант полуди, убије у лудилу друга своја два детета, па се и са̂м убије; из тога се види, сматра он, да ова трагедија има у „већој мери ужасних сцена”.

Питање везано за извор Лукаревићеве драме било је дуго времена отворено и пре Поповићевог разматрања у Прегледу српске књижевности; дакле, да ли је постојао директни антички, или посредни италијански предложак преко кога је дубровачки писац „истомачио” приповест о тебанском краљу? Овим се проблемом позабавио готово четири деценије пре Павла Поповића и Армин Павић у својој Хисторији дубровачке драме, користећи академијски рукопис бр. 1, где у наслову стоји: Athamante tragedia istomačena ро Franu Luccari Burinni, dubrovačkom vlastelinu. Павић се не слаже са старијим историчарима књижевности који тврде да је Лукаревић ову своју трагедију превео са грчког, јер ако би Атаманте био превод са грчког, морали бисмо претпоставити да су у XVI веку заиста постојали старовековни рукописи ове трагедије, којима данас нема трага. Из дубровачког Атаманта се види, тврди Павић, да је у питању превод неке италијанске трагедије XVI века ${ }^{23}$. Армин Павић (Павић 1871в: 44) закључује да грчкога нема ни у трагедији, ни у композицији, ни у говору, а натпис рукописа - „истомачена” нас јасно упућује на то, да је у питању превод и да трагедија није оригинална; ипак, нигде не спомиње италијански изворник Ђиролама Зопиа. Почетком XX столећа, Иван Стојановић само износи један оскудан податак - „Франо Лукари, поријеклом из Србије, приказа много пута своју Атаманту” (Стојановић 1900: 237). Значајнији помак пре Павла Поповића направиће Милан Решетар (Решетар 1902: 205-209) који је довео у везу Лукаревићеву трагедију са истоименим делом италијанског песника Ђиролама Зопиа, које је Лукаревић превео на слободан начин, како су то обично радили сви преводиоци тога доба, проширујући га за неких пет стотина стихова, али и скраћујући понешто, нарочито у прологу (више од стотину стихова). Дакле, Решетар сматра да је овај препев могао настати у последњој декади XVI столећа, након 1597. године када и Зопио ствара своје истоимено дело.

Павле Поповић је сагласан са Решетаровим мишљењем о Зопијевој трагедији као предлошку дубровачком драматичару, те говорећи о проширењима и изменама које је Дубровчанин учинио у односу на италијански изворник, подразумева уобичајен поступак ренесансних преводилаца да преиначују извесне појединости и прилагођавају их сопственој стваралачкој концепцији ${ }^{24}$. Поповић у своме излагању помиње „чудан случај” којим су Фрикс

${ }^{23}$ F. Rački, Djela Frana Lukarevića Burine, Predgovor SPH, X, Zagreb, 1878, str. X-XI; Рачки тачно претпоставља да је у питању превод са италијанског, али не даје подробније податке.

${ }^{24}$ Пратећи доследно италијанску фабулу Лукаревић ипак уноси извесне аутентичне елементе, својствене само његовом делу; на пример, обиље хришћанских реминисценција складно уклопљених у паганску тематику, преко којих је изложио сопствене рефлексије о Богу и загробном животу. У опису „пакљених страна” дозива у свест сећање на дантеовске призоре, те зле последице греха које чекају његовог Атаманта - представника свих људи понесених страшћу, охолошћу и свирепошћу које чека страшна казна. Лукаревићева трагедија садржи многобројне рефлексије о људској таштини, охолости, временитости и појавама које су кореспондирале са 
и Хеле (Атамантова деца из брака са богињом облака Нефелом), избављени од бестијалности тебанског краља подстакнутог мржњом његове друге жене - Кадмове кћери Ино - према овој деци; она их жели заклати на олтару на коме „жеже свети огањ”. У подтексту Поповићеве алузије на несвакидашњи догађај којим су деца избегла уништење, стоји деловање богиње Нефеле и њено старање да у Орхомен пошаље златног овна Креја ${ }^{25}$. Према упутствима „великог непута” титана Атланта, Меркуриа (Меркура), изван зидина града, код мраморног Амфионовог гроба појавиће се златан ован на чијим ће леђима деца - по вољи богова и уз заштиту Јова - отпловити морем. Поповић помиње једну значајну појединост у току драмске радње, а везана је за смрт младе Хеле у мору. Овај детаљ је у складу са митском основом, према којој ће место принцезиног утапања добити касније по њој име Хелеспонт; о постанку поменутог географског назива говори и Џиво Гундулић у VII певању (стр. 41-44) барокног епа Осман.

Преокрет у радњи изазван вољом богова предупредио је жртвовање 26 Хеле и Фрикса, сугестивно дато у опису Лукаревићевог гласника, а у складу са „ужасним сценама” које издваја Поповић. Гласник казује да је „грозне сузе” код присутних изазвала Хеле речима: „Јаох, ћаћко коље ме, а к ћаћку бјежим ја,/ у ком су схране ме и сва моја уфања!” (Лукаревић 1878: 271). Потом је престрављена и скрхана болом молила тебански пук - верујући у његову милост, а не зверску окрутност - да не допусти да је закоље оштрица ножа. Павле Поповић упућује и на опис краљевог силаска с ума, његовог мрачног лудила и бестијалности, које ће узроковати убиство друго двоје деце (Леарха и Мелицерта), али и властито самоубиство. Постепено западање у делиријум и махнитост дочарава хор описујући краљево лице безумног човека, који изгара у гневу јер га мори велико зло. Несвестан свога окружења Атаманте бунца у агонији, дозивајући у свест призор Хелине смрти у морским валовима. Импресивна је визија где му се отварају врата на небу и пролама се сунчева светлост кроз коју види велику звер а од ње му се причини коњ који пасе, и истога часа промени обличје и претвори се у лава, па у пса налик пакленом Керберу; пас се одједном претвори у прасца који

дубровачким окружењем и стањем духова његовог времена; све ово иде у прилог чињеници да је његов превод знатно слободнији и шири - што истиче и Павле Поповић - са обиљем појединости ван основног заплета италијанског изворника.

${ }^{25} \mathrm{O}$ необичној судбини двоје деце сведочи у трагичком тексту један грађанин, који је видео како на „овнићу” у златној одежди (овну златног руна) деца беже у правцу мора. Склизнувши са леђа златоруног овна у морске таласе, док је прелазио Дарданеле, Хеле се утопила и то место је названо Хелеспонт (Мраморно море). Према митском изворишту, појава златоруног овна, Хермесовог дара, везана је за намеру богиње облака Нефеле да спаси своју децу жртвовања; стога га је обавијеног једним облаком спустила на жртвеник, како би заменио децу већ доведену на жртвовање. Сведочанство поменутог актера упућује на разлог појаве овна златног руна у драми (истог оног Креја који је отпловио у Колхиду, а чије је одрано руно поседовао Медејин отац, краљ Ејет, што је с друге стране везано за циклус о Јасону и Аргонаутима).

${ }^{26}$ Сцена је паралелна Аврамовом жртвовању сина Исака, а библијске аналогије нису ретке, с обзиром на присутност елемената христијанизације у Лукаревићевој трагедији. Гласник приповеда како је Фрисо (Фрикс), знајући да им се спрема смрт од оштрице ножа на жртвенику, клекнувши поручио оцу да ништа није згрешио; небо му је сведок и стога своју судбину мирно и без страха прихвата, јер небеса тако налажу. 
Атаманта хтеде зубима „да дере и груби”, а све је ово дело небеске Срџбе послате од Јуноне. Помраченог ума и крвожедан, Атаманте не препознаје сопствене синове мислећи да су младунци лава, а њихова мати Ино лавица и „зла крвница”. Ужасни призори у овој трагедији на које Поповић алудира, најупечатљивији су у сцени убиства синова. Хор жали „дјетешце мило” које је грлило свога избезумљеног оца, а он га је немилостиво убио; срџба богова са небеса подстакла је краљеву крвожедност, па је јурнуо ка жени и другом детету да их усмрти, док су се врисци злих духова опседајући двор чули и изван зидина града. Павле Поповић начелно говори о присуству „у већој мери ужасних сцена" у Лукаревићевој трагедији, која садржи проширења у односу на Зопијеву драму, а поменути пример је један од оних који би били најокрутнији.

У историји српске књижевности Павле Поповић је био први од проучавалаца који је изворно (на основу рукописне и архивске грађе) и систематски приступио истраживању дубровачке књижевности, а поред тога је драгоцено и његово суделовање у покретању и уређивању дубровачког часописа $C p \hbar$. Пишући своје студије о писцима друге половине XVI столећа-Антуну Сасину, Мароју Мажибрадићу, као и Савку Гучетићу Поповић је, поред архивских докумената из Дубровника, такође проучавао и рукописна и штампана дела ових аутора, изводећи на основу њихове темељне анализе прецизне оцене, што је очигледно на примеру трагедије Далида. Павле Поповић је показао да су дубровачки трагичари у својим делима следили оновремене италијанске ствараоце, као и театарске токове ренесансне Европе. Истакао је да су у својим делима остајали верни основној фабули, али су се свесно удаљавали у спољним оквирима, вршећи стваралачку надградњу на постојећи извор у циљу приближавања дубровачкој реалности и ренесансном стању духа. У својим истраживањима он запажа новине које доприносе особености дубровачке трагедије у односу на италијанску; оне се огледају у настојању да се потцртају појединости које су се уклапале у дубровачки живот и менталитет људи. Уочљиве су и у христијанизацији стихова сачињених у маниристичком духу - на шта Поповић скреће пажњу нарочито у трагичком делу Савка Гучетића - са реминисценцијама на модерна схватања уклопљена у оквире античких монолога и дијалога.

Почев од Држићеве трагедије о тројанској краљици, Павле Поповић је пружио допринос сваком тагичком делу понаособ, дајући нове закључке и анализирајући дотадашње ставове у науци. У случају Држићевог дела (вреди истаћи да је Поповић и писац есеја о Новели од Станца и Плакиру), потврдио је да се по питању ауторства Хекубе Ветрановићево сведочење у прилог Држићу обелодани, те коначно изнесе јасан став у науци да је она Држићева, иако је до недавно приписивана Мавру Ветрановићу. Везано за проблем извора Далиде за коју се до Поповићевих истраживања веровало да је синтеза две трагедије Л. Грота, Павле Поповић је учинио пресудан корак својим открићем увођења Ђиралдијеве Орбеке у пети чин дубровачке трагедије; тиме је он први у науци у потпуности расветлио до тада нерешено питање Гучетићевог изворника. Учинио је значајан допринос и својим потврђивањем 
Еурипидових Феничанки као предлошка Бунићеве Јокасте и то преко италијанске прераде Л. Долчеа. Изводећи помну анализу Златарићеве Електре, Поповић је својим закључцима допринео уобличењу званичног става у историји књижевности, по коме је Златарић - за разлику од осталих драматичара - превео своју Електру непосредно из Софокловог оригинала. Надовезујући се на ставове Армина Павића и Милана Решетара, Павле Поповић потврђује чињеницу о Ђироламу Зопиу и његовом Атаманту као извору истоимене Лукаревићеве трагедије; при томе, истражујући пружа у подтексту богато алузивне смернице према којима се открива богатство разноврсних појединости у проширењима и изменама које је учинио дубровачки аутор. Оваквим поступком се и у другим трагедијама показало присуство аутентичне стваралачке надградње, којом су дубровачки писци трагедија уклапали своја дела у ренесансни дубровачки ареал повезујући их са класичним наслеђем.

\section{ЛИТЕРАТУРА}

Бојовић 1992: З. Бојовић, Зачеци дубровачке ренесансне поетике, Зборник у част Војислава Ђурића, Београд, 119-128.

Бунић Бабулинов 1880: M. Bunić Babulinov, Djela, SPH, knj. XI, Zagreb: JAZU. Водник 1913: B. Vodnik, Povijest hrvatske književnosti, I, Zagreb: Matica hrvatska.

Гучетић Бендевишевић 1888: Djela Savka Gučetića Bendeviševića, SPH, knj. XVI, Zagreb: JAZU.

Дер 1938: Ž. Der, Zlatarićev doktorat u Padovi, „Dubrovačke studije”, Zagreb, $73-88$.

Златарић 1899: Djela Dominka Zlatarića, SPH, knj. XXI, Zagreb: JAZU.

Колендић 1905: P. Kolendić, Tri doslije nepoznate pjesme dum Mavra Vetrani: Prilog dubrovačkoj književnosti XVI vijeka, Srđ, god. IV, br. 3-4, Dubrovnik, 134-140.

Колендић 1964: П. Колендић, Разговор о „Хекуби”, Политика, 15. VIII 1959, у: П. Колендић, Из старога Дубровника, прир. М. Пантић, Београд: СКЗ, 127-129.

Комбол 1933: M. Kombol, Talijanski utjecaji u Zlatarićevoj lirici, 247, Zagreb: Rad JAZU, 212-251.

Лукаревић 1878: Djela Frana Lukarevića Burine, SPH, X, Zagreb: JAZU.

Нери 1904: F. Neri, La tragedia italiana del cinquecento, Firenze: Tipografia Galletti e Cocci.

Павић 1871: A. Pavić, Historija dubrovačke drame, Zagreb: JAZU.

Поповић 1909: Павле Поповић, Преглед српске књижевности, Београд.

Поповић 1930: П. Поповић, Савко Гучетић, дубровачки песник XVI века, Глас СКА, 1930, CXXXVIII, 3-58.

Поповић 2000: Павле Поповић - Дубровачке студије, књ. IV, прир. 3. Бојовић, Београд: Завод за уџбенике и наставна средства, 308-359.

Решетар 1902: M. Rešetar, Das original des Atamante von Fr. Lukarević Burina, Archiv für slav. Phil. XXIV, 205-209. 
Решетар 1930: M. Rešetar, Djela Marina Držića, SPH, knj. VII, Zagreb: JAZU. Сламинг 1968: I. Slaming, Hrvatska književnost prije preporoda kao organski dio evropskog književnog kretanja, Forum, 7-8, Zagreb, 707-727.

Стојановић 1900: I. Stojanović, Dubrovačka književnost, Dubrovnik.

Франичевић 1968: М. Franičević, Izvori i tokovi naše renesansne književnosti, Forum, 7-8, Zagreb, 71-97.

Gordana Pokrajac

\section{PAVLE POPOVIC'S CONTRIBUTION OF RESEARCHING RAGUSAN RENAISSANCE TRAGEDY}

(Summary)

Pavle Popovic's research of Ragusan tragedies is important, because he pointed out the fact that the paralel between the classical and Ragusean authors is connected with the Italian tragic genre. This is of essential importance for understanding the comparative relations within the Ragusean tragedy. Popović explained influences from classical epoch and Italian Renaissance, on Ragusan dramatic genre from second part of XVI century; he included five tragedies, starting with Držić's Hecuba, through Bunić's Jocasta, Gučetić's Dalida, Zlatarić's Electra, and finally Lukarević's Athamante. 